\title{
LOCATION OF AN LNG TERMINAL ON THE POLISH COAST - OPTIMAL SOLUTION
}

\section{LOKALIZACJA TERMINALU LNG NA WYBRZEŻU POLSKIM - OPTYMALNE ROZWIĄZANIE}

\author{
Stanisław Gucma \\ Maritime Univeristy of Szczecin \\ Akademia Morska w Szczecinie \\ 70-500 Szczecin Wały Chrobrego 1-2 \\ e-mails: gucma@am.szczecin.pl
}

\begin{abstract}
This article, using a comparative method, estimates navigational and economic risks concerning shipping routes and associated two variants of the terminal location on the Polish coast. The estimated risks specifically refer to LNG tanker passages to and from the planned terminal. The location variants were compared and the optimal solution was indicated.
\end{abstract}

Keywords: safety, economic risk, navigational risk

Streszczenie: W artykule przedstawiono porównawczą metodę szacowania ryzyka nawigacyjnego oraz ekonomicznego na trasach żeglugowych prowadzących do dwóch wariantów lokalizacji terminali LNG na wybrzeżu polskim. Oszacowano ryzyko nawigacyjne i ekonomiczne całego przejścia zbiornikowców LNG porównano warianty lokalizacji i wybrano wariant optymalny.

Słowa kluczowe: bezpieczeństwo, ryzyko ekonomiczne, ryzyko nawigacyjne 


\section{LOCATION OF AN LNG TERMINAL ON THE POLISH COAST - OPTIMAL SOLUTION}

\section{Introduction}

The construction of a marine terminal for handling liquefied natural gas (LNG) is aimed at the diversification of Poland's gas supplies. Today the consumption of natural gas in Poland amounts to approximately 15 billion $\mathrm{m}^{3}$ and in forecasts for the next twenty years the figure is to be doubled. At present, Polish imports of gas have the following structure:

- $70 \%$ from the east,

- $10 \%$ from the west,

- $20 \%$ own resources.

The planned LNG terminal is expected to handle increasing quantities of gas:

- $2011-2.5$ billion $\mathrm{m}^{3}$

- $2016-5.0$ billion $\mathrm{m}^{3}$,

- $2021-7.5$ billion $\mathrm{m}^{3}$.

LNG tankers are employed to carry large quantities of liquefied natural gas (methane $\mathrm{CH}_{4}$ ) at atmospheric pressure and its boiling point, i.e. $-163^{\circ} \mathrm{C}$. LNG carriers resemble huge thermoses of various designs (prismatic, spherical, membrane). Propelled mostly by steam turbines, these ships use boil-off vapours which are burnt in steam boilers.

Cargo capacity is generally given as a size parameter of LNG tankers. Presently the world's largest LNG tanker has a cargo capacity of $145000 \mathrm{~m}^{3}$. Last year a new LNG tanker with over $200.000 \mathrm{~m}^{3}$ capacity was launched. The most numerous group of LNG carriers are those ranging from 125000 to $145000 \mathrm{~m}^{3}$.

The assumptions for the choice of optimal location of an LNG terminal on the Polish coast have been defined as follows: 
1. LNG terminal to be built on the Polish coast will be handling LNG carriers with cargo capacity up to $200000 \mathrm{~m}^{3}$, i.e. with maximum existing parameters:

- length overall $\mathrm{L}_{\mathrm{C}}=300 \mathrm{~m}$,

- breadth $\mathrm{B}=50 \mathrm{~m}$,

- draft $\mathrm{T}=12.0 \mathrm{~m} \div 12.5 \mathrm{~m}$.

2. Safe depth of approach channels for vessel draft of $\mathrm{T}=12.5 \mathrm{~m}$ is about $14.5 \mathrm{~m}$.

3. Along the Polish coast only two realistic locations can actually be pointed out that satisfy the requirement of approach channel depth. These are:

- Port Północny in Gdańsk,

- Port of Świnoujście.

4. Both ports offer a number of variants for LNG terminal design solutions that differ in terms of cargo handling berths, approach channels, turning basins, breakwaters etc.

The choice of the best location and associated solution variant will be made here by employing the comparative method using the following criteria:

- minimization of navigational risk,

- minimization of economic risk.

\section{Realistic possibilities of LNG terminal location on the Polish coast}

The choice of LNG terminal location on the Polish coast is determined by the following factors:

- parameters of LNG carriers presently operated and those under construction in the world as well as those planned for service in the designed terminal; these parameters can be set forth as follows:

- LNG carrier with cargo capacity $\mathrm{V}=145000 \mathrm{~m}^{3}, \mathrm{~L}_{\mathrm{C}}=280 \mathrm{~m}, \mathrm{~B}=$ $45 \mathrm{~m}, \mathrm{~T}=12.0 \mathrm{~m}$;

- LNG carrier with cargo capacity $\mathrm{V}=200000 \mathrm{~m}^{3}, \mathrm{~L}_{\mathrm{C}}=300 \mathrm{~m}, \mathrm{~B}=$ $50 \mathrm{~m}, \mathrm{~T}=12.5 \mathrm{~m}$;

- navigational conditions prevailing in the Baltic,

- requirements for the port infrastructure allowing for safe approach to the harbour by vessels with draft $\mathrm{T}=12.5 \mathrm{~m}$, length $\mathrm{L}_{\mathrm{C}}=300 \mathrm{~m}$ and breadth $\mathrm{B}=50 \mathrm{~m}$.

Taking the above factors into consideration, only two feasible locations for an LNG terminal on the Polish coast, namely:

- Port of Świnoujście, 
- Port Północny in Gdańsk.

The remaining locations on the coast of Poland require the construction of new deep water ports and approach channels, which can only be done with huge financial effort.

Detailed variants of LNG terminal location in each port have been determined on the basis of an analysis of local conditions, restrictions and possibilities as well as consultations with several institutions: PGNiG (Polish Gas Mining and Systems), Szczecin-Świnoujście Port Authority, Gdańsk Port Authority, Maritime Office in Szczecin, Maritime Office in Gdynia [2].

As a result of relevant analyses, the following detailed variants of LNG terminal location were chosen:

\section{Port of Świnoujście}

Detailed variant 1: LNG terminal to be built in the outer harbour (Fig. 1).

Detailed variant 2: LNG terminal to be built in the outer harbour (Fig. 2).

\section{Gdańsk - Port Pólnocny}

Detailed variant 1: at the ore jetty (Fig. 3).

Detailed variant 2: between the ore and LPG jetties (Fig. 3).

Detailed variant 3: next to Naftoport (Fig. 3).

A mathematical model of the area was built for each of the variants. These models are used in simulations of LNG tanker movements.

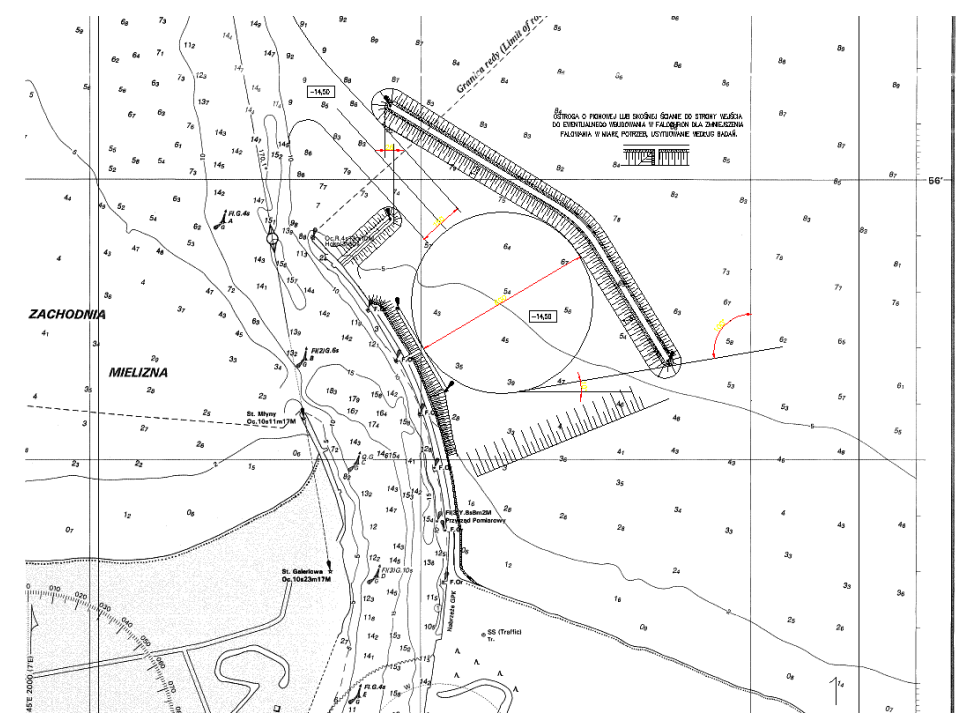

Fig. 1. Świnoujście: LNG terminal design in the outer harbour - detailed variant 1 


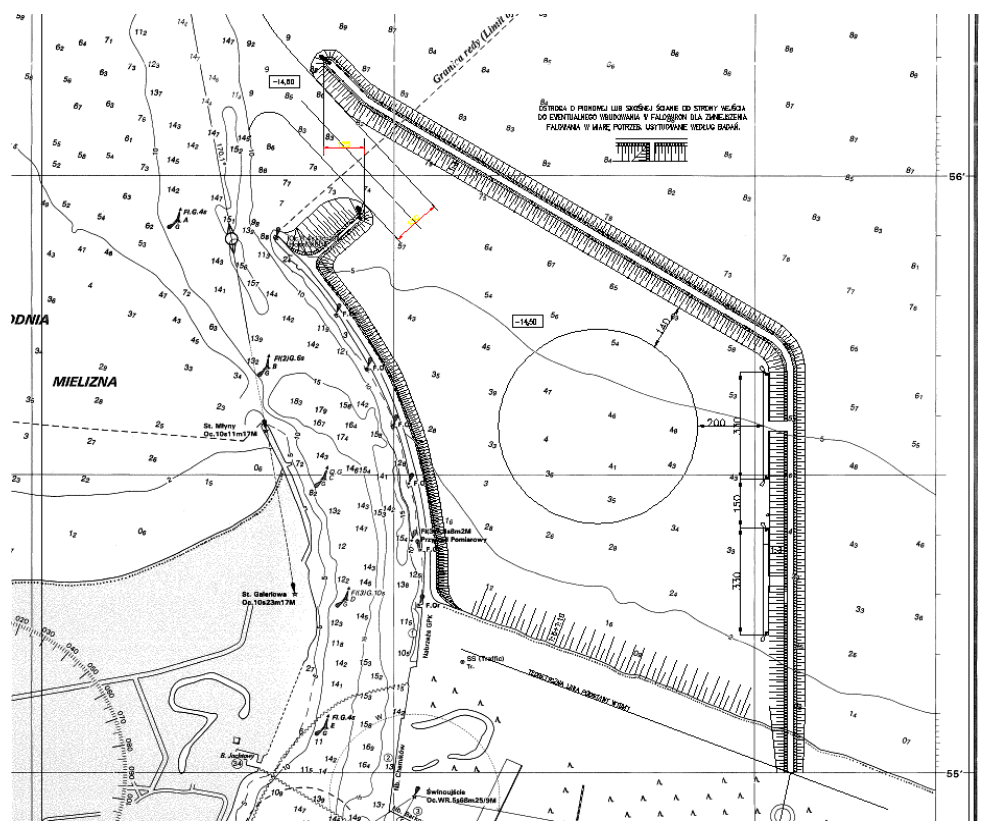

Fig. 2. Świnoujście: LNG terminal in the outer harbour - detailed variant 2 


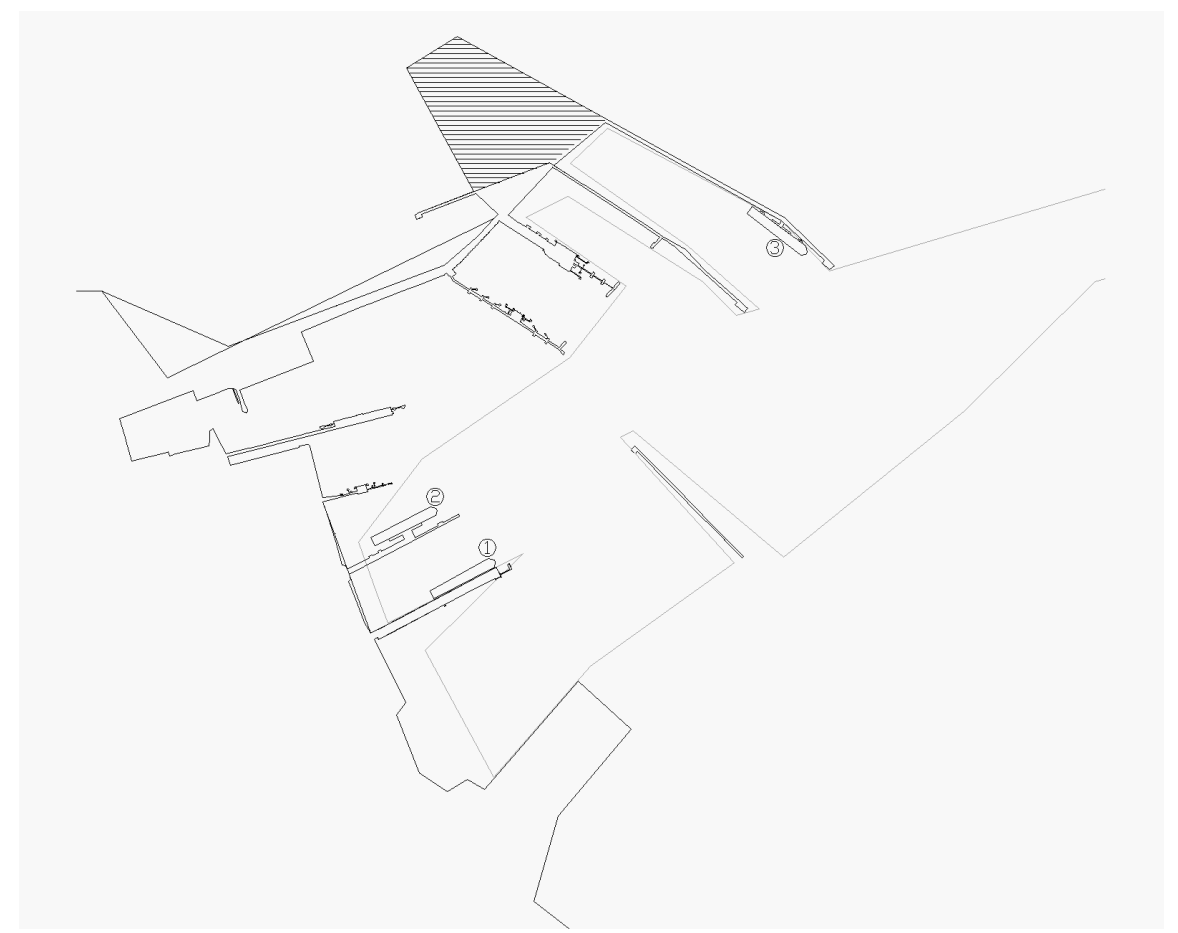

Fig. 3. Gdańsk Port Północny: design of LNG terminal: detailed variant 1 at the ore jetty, detailed variant 2 between the ore and LPG jetties, detailed variant 3 next to Naftoport.

\section{The choice of the optimal LNG terminal location using minimized navigational risk criterion}

An analysis of navigational threats on routes from Danish straits to the prospective LNG terminal allowed to identify hazards prevailing in relevant route sections:

1. The section from Danish straits to the designed anchorages for LNG carriers in Pomorska Bay or Gdanska Bay - the major threat is a collision with another ship.

2. The section from the relevant anchorage to the entrance heads of the terminal in Świnoujście or Gdańsk - the major threat there is ship's grounding on a slope of the dredged waterway. 
3. Entry into the terminal, turning and berthing - the major threat in this area is LNG carrier's collision with port structures, bottom or other ships mooring in the port.

Navigational risk of a passage along the entire route will be determined as a sum of navigational risks at each section:

$$
R=\sum_{i=1}^{3} R_{i}
$$

where: $R_{i}$ - navigational risk at the $i$-th section.

Navigational risk of passing each section will be determined by this equation:

$$
R_{i}=P_{i} \cdot S_{i}
$$

where:

$P_{i}-$ probability of an accident of a given type during a passage of $i$-th route section,

$S_{i}$ - consequences of an accident of a given type during a passage of $i$-th route section,

After substitution we get:

$$
R=\sum_{i=1}^{3} P_{i} \cdot S_{i}
$$

The probability of an accident of a given type (for the major threat) is determined by various methods for each section:

section 1 - methods of Monte Carlo simulations making use of purposebuilt model of vessel traffic in the Baltic;

section 2 - methods of fast time simulations (computer-modelled human being);

section 3 - methods of real time simulations (prepared by the port pilots employed as experts).

The following data were adopted:

- intensity of sailings - one LNG carrier per week,

- present shipping route to Świnoujście east of Rügen,

- route to Gdańsk north of Bornholm. 
Based on simulation studies [2], probabilities of accidents during one voyage for each terminal location were determined:

\section{Port of Świnoujście}

$$
\begin{aligned}
& \text { section } 1-\mathrm{P}_{1}=4.9 \cdot 10^{-5}, \\
& \text { section } 2-\mathrm{P}_{2}=5.0 \cdot 10^{-4}, \\
& \text { section 3: variant } 1-\mathrm{P}_{3}=7.0 \cdot 10^{-3}, \\
& \quad \text { variant } 2-\mathrm{P}_{3}=7.0 \cdot 10^{-3} .
\end{aligned}
$$

\section{Gdańsk - Port Pólnocny}

$$
\begin{aligned}
& \text { section } 1-\mathrm{P}_{1}=1.16 \cdot 10^{-4}, \\
& \text { section 2- } \mathrm{P}_{2}=3.37 \cdot 10^{-4}, \\
& \text { section 3: } \\
& \operatorname{variant} 1-\mathrm{P}_{3}=7.0 \cdot 10^{-3}, \\
& \quad \text { variant } 2-\mathrm{P}_{3}=1.4 \cdot 10^{-2}, \\
& \quad \text { variant } 3-\mathrm{P}_{3}=7.0 \cdot 10^{-3} .
\end{aligned}
$$

In marine traffic engineering the consequences of accidents are determined from this energy equation [1]:

$$
S=\frac{E_{i}}{E_{d o p}}
$$

where:

$E_{i} \quad$ - kinetic energy of the ship at the moment of accident [kNm];

$E_{d o p}$ - maximum kinetic energy that does not cause any damage to the ship and does not require rescue action $[\mathrm{kNm}]$.

Therefore, consequences of a specific type of accident depend on kinetic energy the ship has at the moment the accident occurs. From the analysis of navigational conditions prevailing in particular route sections and commonly used tactics of manoeuvring a ship of similar size, speeds at which an LNG carrier will be moving within those sections were determined regardless of the location variant. These speeds are:

section 1 - 20 knots,

section 2 - 7 knots,

section 3 - 3 knots (assistance of four tugs).

An accident in which a gas carrier hits a fairway slope or collides with a port structure at a speed of three knots does not cause major damage and no rescue operation is needed. The ship is capable of refloating by itself or with 
help from tugs assisting the manoeuvring ship. For these reasons the consequences of this type of accidents at a speed of three knots can be assumed to equal one $\left(S_{3}=1\right)$. Approximately, it can be assumed that accidents in all the route sections are of similar character and their consequences are directly proportional to squared speed, i.e.:

section $1 \mathrm{~S}_{1}=44$,

section $2 \quad \mathrm{~S}_{2}=5.4$,

section $3 \quad \mathrm{~S}_{3}=1$.

Substituting for the probabilities and accident consequences for relevant route sections we obtain navigational risks of passing along the examined route, correspondingly, for each detailed location variant:

\section{Port of Świnoujście}

variant $1 \mathrm{R}=1.186 \cdot 10^{-2}$,

variant $2 \mathrm{R}=1.186 \cdot 10^{-2}$,

\section{Gdańsk - Port Pólnocny}

variant $1 \mathrm{R}=1.348 \cdot 10^{-2}$,

variant $2 \mathrm{R}=2.048 \cdot 10^{-2}$,

variant $3 \mathrm{R}=1.348 \cdot 10^{-2}$.

By analyzing the above quantities it was found that both variants of Świnoujście location are the safest, whereas the variant 2 of the port of Gdansk LNG terminal is least safe.

Additional threats that are not considered in the method herein applied are created by turning manoeuvres resulting from the need to berth an LNG tanker with its bow facing the basin exit. Both variants of Swinoujscie location and variants 1 and 2 of Port Północny in Gdansk have turning basins sheltered from waves. Only the turning area in variant 3 of Port Północny location is not sheltered and subject to wave action.

Taking into consideration the above remarks we can point out the safe variants of LNG terminal location on the Polish coast:

- Port of Świnoujście: variant 1 (Fig. 1), variant 2 (Fig. 2),

- Port Północny in Gdańsk: variant 1 (Fig. 3).

From the viewpoint of an LNG carrier with $200.000 \mathrm{~m}^{3}$ capacity passing from Danish straits to the LNG terminal, both variants located in the port of Świnoujście are the safest. 


\section{The choice of the optimal lng terminal location variant using mini- mized economic risk criterion}

Economic risk of an accident of an LNG carrier along the examined route was determined from this relationship:

$$
R_{e}=\sum_{i=1}^{3} R_{e i} \quad[\mathrm{USD} / \text { year }]
$$

$R_{e i}$ - economic risk of an accident at the $i$-th section [USD/year].

Economic risk of an accident of an LNG carrier at each section is determined from this relationship:

$$
R_{e i}=P_{i} \cdot I \cdot S_{e i} \quad[\mathrm{USD} / \text { year }]
$$

where:

$I \quad$ - yearly intensity of LNG carrier traffic $\left[\right.$ year $^{-1}$ ], $S_{e i}-$ cost of consequences of an accident at the $i$-th section [USD],

after substitution:

$$
R_{e}=\sum_{i=1}^{3} P_{i} \cdot I \cdot S_{e i} \quad[\mathrm{USD} / \text { year }]
$$

The cost of accident consequences comes down to the estimation of costs of a characteristic accident that may occur in a given section of the examined route. The cost of accident consequences for the $i$-th route section can be estimated by the following relationship:

$$
S_{e i}=\sum_{j=1}^{5} K_{i j}[\mathrm{USD}]
$$

where:

$K_{s i 1}$ - costs of removing ship accident consequences or ship's loss,

$K_{s i 2}$ - costs of cargo loss,

$K_{s i 3}$ - costs of removing consequent fairway malfunction,

$K_{s i 4}$ - costs of marine environment pollution clearance operations,

$K_{s i 5}$ - costs due to damage caused by fairway blockage.

The evaluation of particular costs depends on the type of accident and that is why they will be considered separately for each route section where accidents are of different nature.

In section 1 the potentially major threat is an LNG carrier's collision with another ship or ships. It is expected that such collision $(S=44)$ will re- 
sult in leaks in cargo tank(s) and ignition of gas, which will finally lead to the loss of personnel, vessel and cargo. In such cases marine environment pollution is not taken into account. The total cost of collision consequences can be estimated as follows:

$$
S_{e 1}=\sum_{j=1}^{4} K_{1 j} \quad[\mathrm{USD}]
$$

where:

$K_{11}$ - cost of the LNG carrier,

$K_{12}$ - costs connected with the loss of personnel,

$K_{13}$ - costs of lost cargo,

$K_{14}-$ costs of the rescue operation.

The following costs have been assumed:

- LNG carrier with cargo capacity of $145.000 \mathrm{~m}^{3}$ - about 80 million USD,

- loss of 30 crewmembers - about 30 million USD,

- loss of cargo in the fully laden vessel - 30 million USD,

- two day rescue operation on the Baltic Sea - about 500000 USD.

After calculations, it can stated that the costs of accident consequences in section 1 are equal to:

$$
\begin{array}{ll}
S_{e 1}=140.5 \text { million USD } & \text { (laden ship) } \\
S_{e 1}=110.5 \text { million USD } & \text { (ship under ballast). }
\end{array}
$$

In section 2 the prevailing threat an LNG carrier faces is that it can hit the underwater slope at the boundary of the deepened fairway. Average consequences of such accident amount to $S=5.4$. It is predicted that although this type of accident $(S \leq 10)$ will not cause any leaks from cargo tanks, it may result in local hull damage $[1,2]$. If this happens, rescue action is needed to get the vessel to refloat and, if necessary, to repair the damaged hull. The costs of such accident consequences can be estimated as follows:

$$
S_{e 2}=\sum_{j=1}^{2} K_{2 j} \quad[\mathrm{USD}]
$$

where:

$K_{21}$ - cost of removal of ship accident consequences,

$K_{22}$ - costs due to losses caused by waterway blockage.

The elimination of LNG carrier's grounding consequences generates costs connected with the following reasons:

- rescue operation, 
- ship's repair,

- ship's downtime from the accident to repair completion.

The cost of ship accident consequences elimination has been estimated by a method presented at "Marine Traffic Engineering" [1], in which the total pull power of the tugs needed to haul a grounded vessel off the ground, time of ship's stay in the dock and repair scope are determined as the function of accident consequences $(S=5,4)$. Using these quantities the following have been specified:

- additional tug power needed to get the vessel to refloat - $12.000 \mathrm{HP}$,

- time of rescue operation: one day.

The costs due to losses caused by port blockage - Szczecin and Świnoujście in one case and Port Północny in Gdańsk in the other - have been restricted to the costs of vessels' stay on the roads or in the respective port; these were based on traffic intensity and the average size of vessels calling at these ports.

The traffic intensity in these ports forecast for the year 2015 can be adopted as follows [2]:

- Ports of Świnoujście and Szczecin - 12000 [number of ships in a year] (average size ship - 5000 DWT),

- Gdańsk - Port Północny - 1000 [number of ships in a year] (average size ship - 20000 DWT).

The above assumptions were used for calculating approximate costs of rescue operation, costs of repairs and costs of the gas carrier being out of service, and those associated with the costs of vessels' waiting on the road and in the port associated with the waterway blockade; these costs are presented in Table 1.

Table 1. The costs of rescue operation, repairs and ship's laytime calculated per one accident of average consequences

\begin{tabular}{|c|c|c|c|c|}
\hline Port & $\begin{array}{c}\text { Costs of } \\
\text { rescue opera- } \\
\text { tion }\end{array}$ & $\begin{array}{c}\text { Costs of } \\
\text { repairs and } \\
\text { ship's exclu- } \\
\text { sion from } \\
\text { service }\end{array}$ & $\begin{array}{c}\text { Costs of ships' } \\
\text { waiting on the } \\
\text { road and in } \\
\text { ports }\end{array}$ & $\begin{array}{c}\text { Costs of esti- } \\
\text { mated conse- } \\
\text { quences of the } \\
\text { accident in sec- } \\
\text { tion 2 } \\
\boldsymbol{S}_{\boldsymbol{e} 2}\end{array}$ \\
\hline Port of Świnoujście & 200000 USD & 700000 USD & 300000 USD & $1.2 \mathrm{mln}$ USD \\
\hline Gdańsk - Port Północny & 200000 USD & 700000 USD & 100000 USD & 1 mln USD \\
\hline
\end{tabular}


In section 3 the major threat is a collision of an LNG carrier with a port structure or mooring vessel/s. In this case average consequences equal $S=1$. It is predicted that this type of accident will not result in tank leaks and will only lead to hull indentation or breach. This kind of accident does not require a rescue operation nor will cause waterway blockade. The consequential costs of such accidents can be estimated as follows:

$$
S_{e 3}=\sum_{j=1}^{2} K_{3 j} \quad[\mathrm{USD}]
$$

where:

$K_{31}$ - costs of eliminating the consequences of vessel's accident,

$K_{32}$ - costs of eliminating the consequences of an accident involving port structures or other ships mooring in the port.

The costs of eliminating the consequences of an LNG carrier accident only consist of costs of the vessel's repair and its resultant downtime. Taking into consideration low consequences of the accident $(S=1)$ it was approximately adopted that $K_{31} \approx K_{32} \approx 100000$ USD, i.e.:

$$
S_{e 3}=0.2 \text { million USD. }
$$

Economic risk of the particular variants of the LNG terminal location are set forth in Table 2.

Table 2. Economic risk of the examined variants of the LNG terminal location

\begin{tabular}{|c|c|}
\hline Location variant & Economic risk $R_{e}[\mathrm{USD} /$ year $]$ \\
\hline $\begin{array}{l}\text { Port of Świnoujście } \\
\text { variant 1 }\end{array}$ & 0.815 million \\
variant 2 & 0.815 million \\
\hline Gdańsk - Port Północny & \\
variant 1 & 1.63 million \\
variant 2 & 1.77 million \\
variant 3 & 1.63 million \\
\hline
\end{tabular}

An analysis of economic risk at each section of the examined variants of the LNG terminal location (Table 2) allows to unequivocally claim that the economic risk is twice lower in the case of Świnoujscie location $\left(R_{e} \approx 0.8\right.$ million USD/year) as compared with Gdańsk location $\left(R_{e} \approx 1.6\right.$ million USD/year).

\section{Conclusions}

The comparative method used in this article helped to estimate navigational and economic risks on the shipping route divided into three sections, in 
which various threats to sailing ships are present and vessels proceed at various speeds. The developed method was applied for selecting the safest location of an LNG terminal on the Polish coast. The analysis comprised two detailed LNG terminal location variants in Świnoujście (Figures 1 and 2) and three detailed variants in Port Północny in Gdańsk (Fig. 3).

It was found that safe terminal locations are:

- Port of Świnoujście: variants 1 and 2 - navigational risk $\mathrm{R}=1.186 \cdot 10^{-2}$,

- Port Północny in Gdańsk: variant 1 - navigational risk $\mathrm{R}=1.348 \cdot 10^{-2}$.

The safest passage of an LNG carrier with cargo capacity of $145000 \mathrm{~m}^{3} \div$ $200.000 \mathrm{~m}^{3}$ from Danish straits to the designed terminal is that involving both Świnoujście location variants.

The studies, which aimed at defining the optimal location of an LNG terminal, were also based on the economic risk criterion; in these studies the results of simulation tests were used.

It was found that economic risk is twice lower for the Świnoujscie location:

- Port of Świnoujście: variants 1 and 2 - economic risk $\left(R_{e} \approx 0.8\right.$ million USD/year),

- Port Północny in Gdańsk: variant 1 - economic risk $\left(R_{e} \approx 1.6\right.$ million USD/year).

Comparisons of realistic variants of the LNG terminal location on the Polish coast, performed with the use of the methods of navigational and economic risks, lead to the conclusion that the safest site for the terminal is an outer harbour in Świnoujście.

Assumptions and approximations adopted while estimating the economic risk are possible due to the comparative nature of the method because similar errors are made within estimation procedures for each of the compared variants.

This article was written within the framework of the development project: Development of the most effective solution to the construction of marine LNG terminal in Poland. Determination of the optimal parameters of the terminal and corresponding waterways and conditions of its safe operation, no R10 005 01, financed by the Ministry of Science and Higher Education.

\section{Bibliography}

1. Gucma S.: Inżynieria ruchu morskiego. Okrętownictwo i Żegluga, Gdańsk 2001.

2. Raport roczny z realizacji projektu rozwojowego (za 2007 r.) pt.: Opracowanie najbardziej efektywnego rozwiązania budowy morskiego terminalu rozładunkowego gazu płynnego LNG w Polsce. Określenie optymalnych parametrów terminalu i dróg wodnych prowadzących do niego oraz warunków jego bezpiecznej eksploatacji”. AM, Szczecin 2007. 


\section{LOKALIZACJA TERMINALU LNG NA WYBRZEŻU POLSKIM - OPTYMALNE ROZWIĄZANIE}

\section{Wprowadzenie}

Budowa morskiego terminalu do przeładunku płynnego gazu ziemnego (LNG) ma służyć dywersyfikacji źródeł dostaw gazu do Polski. Obecnie zużycie gazu ziemnego w Polsce wynosi ok. 15 mld. $\mathrm{m}^{3}$ i według prognoz do 2028 roku ulegnie podwojeniu. Aktualne źródła dostaw gazu do Polski to:

- $70 \%$ ze wschodu,

- $10 \%$ z zachodu,

- $20 \%$ zasoby własne.

Planuje się, że budowany terminal LNG będzie przeładowywał następujące ilości gazu:

- 2011 rok $-2,5$ mld. $\mathrm{m}^{3}$,

- 2016 rok $-5,0$ mld. $\mathrm{m}^{3}$,

- 2021 rok $-7,5$ mld. $\mathrm{m}^{3}$.

Statki LNG (Liquified Natural Gas) służą do przewozu dużej ilości skroplonego gazu naturalnego $\left(\right.$ metan $\left.\mathrm{CH}_{4}\right)$ w temperaturze wrzenia przy ciśnieniu atmosferycznym to jest $-163^{\circ} \mathrm{C}$. Gazowce LNG to w zasadzie termosy o zbiornikach różnego typu (pryzmatyczne, kuliste, membranowe). Napędzane są przeważnie turbinami parowymi, a ich paliwem są wyparki gazu LNG spalane w kotłach parowych.

Wielkość gazowców LNG określana jest ich pojemnością ładunkowa. Obecnie największy na świecie gazowiec LNG posiada pojemność ładunkową $145.000 \mathrm{~m}^{3}$. W ubiegłym roku ukończono budowę gazowca LNG o pojemności ponad $200.000 \mathrm{~m}^{3}$. Najliczniejszą grupę stanowią gazowce LNG o pojemności ładunkowej rzędu $125.000 \div 145.000 \mathrm{~m}^{3}$.

Założenia dotyczące wyboru optymalnej lokalizacji terminali LNG na wybrzeżu polskim określono następująco:

1. Terminal LNG budowany na wybrzeżu polskim będzie obsługiwał gazowce LNG

o pojemności ładunkowej do $200000 \mathrm{~m}^{3}$, czyli o maksymalnych parametrach rzędu:

- długość całkowita $\mathrm{L}_{\mathrm{C}}=300 \mathrm{~m}$,

- szerokość $\mathrm{B}=50 \mathrm{~m}$,

- zanurzenie $\mathrm{T}=12,0 \mathrm{~m} \div 12,5 \mathrm{~m}$. 
5. Wymagana bezpieczna głębokość torów podejściowych dla zanurzenia gazowca

$\mathrm{T}=12,5 \mathrm{~m}$ wynosi około $14,5 \mathrm{~m}$.

6. Na wybrzeżu polskim istnieją jedynie dwie realne lokalizacje spełniające warunek głębokości torów podejściowych. Są to:

- Port Północny w Gdańsku,

- Port Świnoujście.

7. W obu portach istnieje szereg wariantów rozwiązań budowy terminalu LNG różniących się lokalizacją stanowisk przeładunkowych, torów podejściowych, obrotnic, falochronów itp.

Wybór najkorzystniejszej lokalizacji i wariantu rozwiązań zostanie przeprowadzony metodą porównawczą przy wykorzystaniu następujących kryteriów:

- minimalizacji ryzyka nawigacyjnego,

- minimalizacji ryzyka ekonomicznego.

\section{Realne możliwości lokalizacji terminalu LNG na wybrzeżu polskim}

Wybór lokalizacji terminalu LNG na wybrzeżu polskim determinują następujące czynniki:

- parametry zbiornikowców LNG eksploatowanych i budowanych obecnie na świecie oraz przewidywanych do eksploatacji $\mathrm{w}$ projektowanym terminalu, które można określić następująco:

- gazowiec LNG o pojemności ładunkowej $\mathrm{V}=145.000 \mathrm{~m}^{3}, \mathrm{~L}_{\mathrm{C}}=$ $280 \mathrm{~m}, \mathrm{~B}=45 \mathrm{~m}, \quad \mathrm{~T}=12,0 \mathrm{~m}$;

- gazowiec LNG o pojemności ładunkowej $\mathrm{V}=200.000 \mathrm{~m}^{3}, \mathrm{~L}_{\mathrm{C}}=$ $300 \mathrm{~m}, \mathrm{~B}=50 \mathrm{~m}, \quad \mathrm{~T}=12,5 \mathrm{~m}$;

- warunki nawigacyjne panujące na Bałtyku,

- wymagania dotyczące istnienia odpowiedniej infrastruktury portowej pozwalającej na bezpiecznym podejściu do portu statków o zanurzeniu $\mathrm{T}=12,5 \mathrm{~m}$, długości $\mathrm{L}_{\mathrm{C}}=300 \mathrm{~m}$ i szerokości $\mathrm{B}=50 \mathrm{~m}$.

Biorąc pod uwagę powyższe czynniki istnieją jedynie dwie realne lokalizacje terminalu LNG na wybrzeżu polskim. Są to:

- Port Świnoujście,

- Port Północny w Gdańsku.

Pozostałe lokalizacje na wybrzeżu polskim wymagają budowy nowych głębokowodnych portów i torów podejściowych, co wiąże się z ogromnymi nakładami inwestycyjnymi.

Szczegółowe warianty lokalizacji terminalu LNG w poszczególnych portach określono $\mathrm{W}$ oparciu o analizę lokalnych warunków, ograniczeń i możliwości oraz konsultacji prowadzonych z następującymi instytucjami: 
PGNiG, Zarząd Portu Szczecin-Świnoujście, Zarząd Portu Gdańsk, Urząd Morski w Szczecinie, Urząd Morski w Gdyni [2].

W wyniku przeprowadzanych analiz wybrano następujące szczegółowe warianty lokalizacji LNG:

\section{Port Świnoujście}

Wariant szczegółowy 1: Budowa terminalu LNG w awanporcie (rys. 1).

Wariant szczegółowy 2: Budowa terminalu LNG w porcie zewnętrznym (rys. 2).

\section{Gdańsk - Port Północny}

Wariant szczegółowy 1 przy pirsie rudowym (rys. 3).

Wariant szczegółowy 2 pomiędzy pirsem rudowym i LPG (rys. 3).

Wariant szczegółowy 3 obok Naftoportu (rys. 3).

Dla każdego z realnych wariantów został zbudowany model matematyczny akwenu. Modele te są wykorzystywane w badaniach symulacyjnych ruchu gazowców LNG.



Rys. 1. Świnoujście: budowa terminalu LNG w awanporcie - wariant szczegółowy 1 


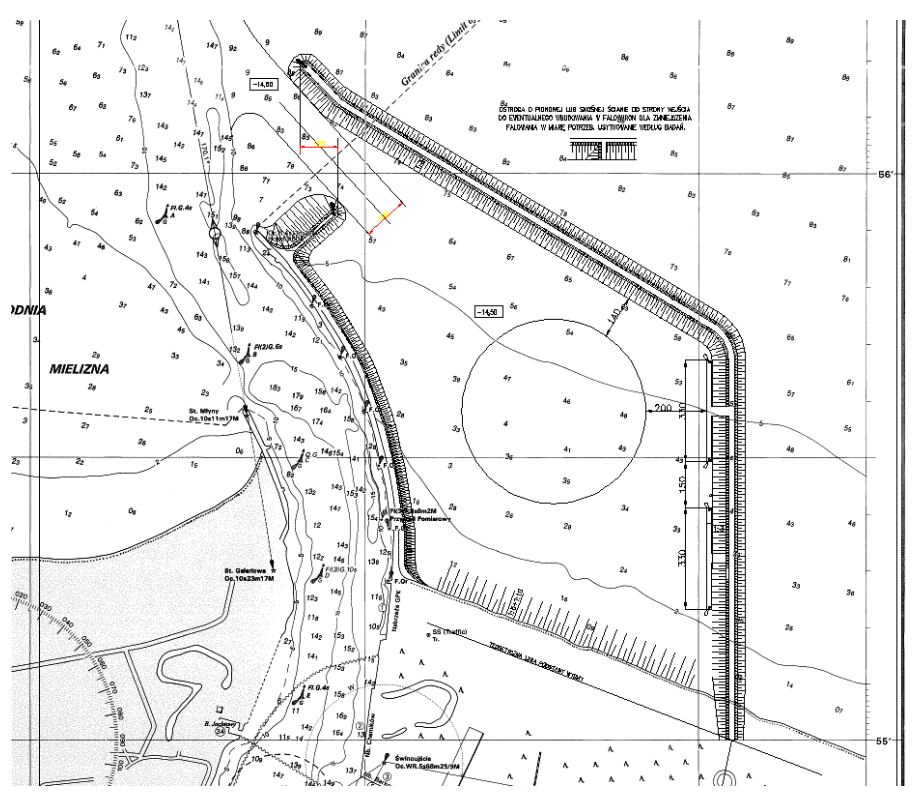

Rys. 2. Świnoujście: budowa terminalu LNG w awanporcie - wariant szczegółowy 2

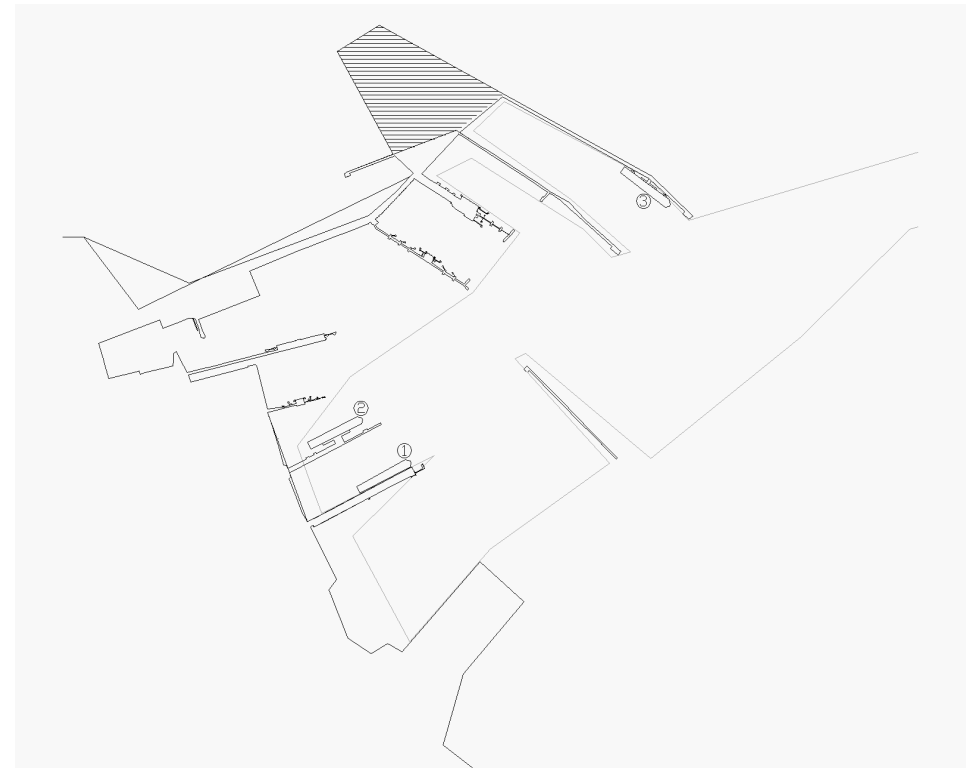

Rys. 3. Gdańsk Port Północny: budowa terminalu LNG: wariant szczegółowy $\mathrm{nr} 1$ przy pirsie rudowym, wariant szczegółowy $\mathrm{nr} 2$ pomiędzy pirsem rudowym i LPG, wariat szczegółowy nr 3 obok Naftoportu. 
5. Wybór optymalnego wariantu lokalizacji terminalu LNG zastosowaniu kryterium minimalizacji ryzyka nawigacyjnego

przy

Analizując zagrożenia nawigacyjne na trasach od cieśnin duńskich do odpowiedniego terminalu LNG określono dominujące zagrożenia na odpowiednich odcinkach tej trasy:

1. Odcinek od cieśnin duńskich do projektowanych kotwicowisk gazowców LNG na Zatoce Pomorskiej i Gdańskiej - dominującym zagrożeniem jest tu kolizja gazowca $\mathrm{z}$ innym statkiem.

2. Odcinek od odpowiednich kotwicowisk do główek wejściowych terminalu w Świnoujściu i Gdańsku - dominującym zagrożeniem jest tu wejście statku na skarpy pogłębionego toru wodnego.

3. Wejście do terminalu, obracanie i cumowanie - dominującym zagrożeniem jest tu zderzenie gazowca LNG $\mathrm{z}$ konstrukcjami hydrotechnicznymi, dnem oraz cumującymi w porcie innymi statkami.

Ryzyko nawigacyjne przejścia całej analizowanej trasy zostanie określone jako suma ryzyk nawigacyjnych przejścia poszczególnych odcinków:

$$
R=\sum_{i=1}^{3} R_{i}
$$

gdzie: $R_{i}$ - ryzyko nawigacyjne $i$-tego odcinka.

Ryzyko nawigacyjne przejścia każdego z odcinków zostanie określone według następującej zależności:

$$
R_{i}=P_{i} \cdot S_{i}
$$

gdzie:

$P_{i}$ - prawdopodobieństwo wypadku określonego typu, przy przejściu $i$ tego odcinka trasy,

$S_{i}$ - skutki wypadku określonego typu, przy przejściu $i$-tego odcinka trasy,

po podstawieniu:

$$
R=\sum_{i=1}^{3} P_{i} \cdot S_{i}
$$


Prawdopodobieństwo wystapienia wypadku określonego typu (dla dominującego zagrożenia) określane jest różnymi metodami dla poszczególnych odcinków:

odcinek 1 - metody symulacji Monte Carlo wykorzystujące specjalnie zbudowany model ruchu statków na Bałtyku;

odcinek 2 - metody symulacji autonomicznej w czasie przyśpieszonym (modelowanie człowieka);

odcinek 3 - metody symulacji nieautonomicznej w czasie rzeczywistym (wykonują piloci odpowiednich portów, jako eksperci).

W badaniach przyjęto:

- intensywność wejść - 1 gazowiec LNG na tydzień,

- obecną trasę żeglugową do Świnoujścia na wschód od Rugii,

- trasę do Gdańska na północ od Bornholmu.

W oparciu o wyniki badań symulacyjnych [2] określono prawdopodobieństwa wypadków w jednej podróży dla poszczególnych lokalizacji:

\section{Port Świnoujście}

odcinek $1-\mathrm{P}_{1}=4,9 \cdot 10^{-5}$,

odcinek $2-\mathrm{P}_{2}=5,0 \cdot 10^{-4}$,

odcinek 3: wariant $1-\mathrm{P}_{3}=7,0 \cdot 10^{-3}$, wariant $2-\mathrm{P}_{3}=7,0 \cdot 10^{-3}$.

\section{Gdańsk - Port Pólnocny}

odcinek $1-\mathrm{P}_{1}=1,16 \cdot 10^{-4}$, odcinek $2-\mathrm{P}_{2}=3,37 \cdot 10^{-4}$,

odcinek 3: wariant $1-\mathrm{P}_{3}=7,0 \cdot 10^{-3}$, wariant $2-\mathrm{P}_{3}=1,4 \cdot 10^{-2}$, wariant $3-\mathrm{P}_{3}=7,0 \cdot 10^{-3}$.

Skutki wypadków w inżynierii ruchu morskiego określa się na podstawie następującej zależności energetycznej [1]:

$$
S=\frac{E_{i}}{E_{d o p}}
$$

gdzie:

$E_{i} \quad$ - energia kinetyczna statku w momencie wypadku $[\mathrm{kNm}] ;$ 
$E_{d o p}$ - maksymalna energia kinetyczna, która jeszcze nie powoduje uszkodzeń statku oraz nie wymaga rozpoczęcia akcji ratowniczej $[\mathrm{kNm}]$.

Skutki wypadków określonego typu zależą więc od energii kinetycznej, jaką posiada statek w momencie wypadku. Analizując warunki nawigacyjne na poszczególnych odcinkach tras oraz stosowaną taktykę manewrowania statków podobnej wielkości przyjęto prędkości jakimi będzie poruszał się gazowiec LNG na tych odcinkach niezależnie od wariantu lokalizacji. Są to:

odcinek 120 węzłów,

odcinek 27 węzłów,

odcinek 33 węzły (asysta 4 holowników).

Wypadek polegający na wejściu gazowca na skarpę toru lub zderzeniu z konstrukcjami hydrotechnicznymi przy prędkości 3 węzłów nie powoduje dużych uszkodzeń oraz nie wymagane jest przeprowadzanie akcji ratowniczej po jego zajściu. Zejście ze skarpy toru następuje samodzielnie lub przy pomocy asystujących przy tych manewrach holowników. Z powyższych powodów skutki tego typu wypadków przy prędkości 3 węzły można przyjąć jako równe jedności $\left(S_{3}=1\right)$. $Z$ pewnym przybliżeniem można przyjąć, że wypadki na wszystkich odcinkach mają podobny charakter a ich skutki są wprost proporcjonalne do kwadratów prędkości, czyli:

odcinek $1 \quad \mathrm{~S}_{1}=44$,

odcinek $2 \quad \mathrm{~S}_{2}=5,4$,

odcinek $3 \quad \mathrm{~S}_{3}=1$.

Podstawiając prawdopodobieństwa i skutki wypadków odpowiednich odcinków otrzymano ryzyko nawigacyjne przejścia całej analizowanej trasy dla poszczególnych szczegółowych wariantów lokalizacji:

\section{Port Świnoujście}

wariant $1 \mathrm{R}=1,186 \cdot 10^{-2}$,

wariant $2 \mathrm{R}=1,186 \cdot 10^{-2}$,

\section{Gdańsk - Port Pólnocny}

wariant $1 \mathrm{R}=1,348 \cdot 10^{-2}$,

wariant $2 \mathrm{R}=2,048 \cdot 10^{-2}$,

wariant $3 \mathrm{R}=1,348 \cdot 10^{-2}$. 
Analizując powyższe wielkości stwierdzono, że najbardziej bezpieczną jest lokalizacja świnoujska (oba warianty lokalizacji), natomiast najmniej bezpiecznym jest wariant 2 lokalizacji terminalu LNG w Porcie Gdańskim.

Dodatkowe zagrożenia nieuwzględniane $\mathrm{w}$ opisywanej metodzie generują manewry obracania gazowców LNG, gdyż muszą być one cumowane dziobem do wyjścia. W obu wariantach lokalizacji świnoujskiej oraz w 1 i 2 wariancie lokalizacji w Porcie Północnym obrotnice sa osłonięte od działania fali. Jedynie obrotnica w 3 wariancie lokalizacji w Porcie Północnym jest odsłonięta i narażona na działanie fali.

Biorąc pod uwagę powyższe analizy można uznać jako bezpieczne następujące warianty lokalizacji terminalu LNG na wybrzeżu polskim:

- Port Świnoujście: 1 wariant lokalizacji (rys. 1), 2 wariant lokalizacji (rys. 2),

- Port Północny w Gdańsku: 1 wariant lokalizacji (rys. 3).

Najbezpieczniejszymi, z punktu widzenia przejścia gazowca LNG o pojemności ładunkowej $200.000 \mathrm{~m}^{3}$ od cieśnin duńskich do terminalu LNG, są oba warianty zlokalizowane w Porcie Świnoujście.

\section{Wybór optymalnego wariantu lokalizacji terminalu LNG przy zastosowaniu kryterium minimalizacji ryzyka ekonomicznego}

Ryzyko ekonomiczne wypadku gazowca na analizowanej trasie określono według zależności:

$$
R_{e}=\sum_{i=1}^{3} R_{e i} \quad[\mathrm{USD} / \mathrm{rok}]
$$

$R_{e i}$ - ryzyko ekonomiczne wypadku na $i$-tym odcinku [USD/rok].

Ryzyko ekonomiczne wypadku gazowca LNG na każdym z odcinków określane jest według następującej zależności:

$$
R_{e i}=P_{i} \cdot I \cdot S_{e i} \quad[\mathrm{USD} / \mathrm{rok}]
$$

gdzie:

$I$ - roczna intensywność ruchu gazowców LNG $\left[\mathrm{rok}^{-1}\right]$,

$S_{e i}$ - koszt skutków wypadku na $i$-tym odcinku [USD],

po podstawieniu:

$$
R_{e}=\sum_{i=1}^{3} P_{i} \cdot I \cdot S_{e i} \quad[\mathrm{USD} / \mathrm{rok}]
$$


Koszt skutków wypadku sprowadza się do określenia kosztów wypadku charakterystycznego dla określonego odcinka badanej trasy. Koszt skutków wypadku dla $i$-tego odcinka trasy można określić według następującej zależności:

$$
S_{e i}=\sum_{j=1}^{5} K_{i j} \quad[\mathrm{USD}]
$$

gdzie:

$K_{s i l}$ - koszty usunięcia skutków wypadku statku lub utraty statku,

$K_{s i 2}$ - koszty strat przewożonych ładunków,

$K_{s i 3}$ - koszty usunięcia awarii drogi wodnej,

$K_{s i 4}$ - koszty usunięcia zanieczyszczeń środowiska morskiego,

$K_{s i 5}$ - koszty wynikające ze start spowodowanych zablokowaniem drogi wodnej.

Ocena poszczególnych kosztów składowych zależy od rodzaju wypadku i dlatego zostaną one rozpatrzone oddzielnie dla poszczególnych odcinków trasy, na których występują różne rodzaje wypadków.

$\mathrm{Na}$ odcinku 1 dominującym zagrożeniem jest kolizja gazowca z innymi statkami. Przewiduje się, że taka kolizja $(S=44)$ doprowadzi do rozszczelnienia zbiornika(ów) i zapłon gazu, a w rezultacie utratę gazowca LNG, załogi i ładunku. Przy tego typu wypadkach nie przewiduje się zanieczyszczenia środowiska morskiego. Koszt oceny skutków tego typu kolizji można określić następująco:

$$
S_{e 1}=\sum_{j=1}^{4} K_{1 j} \quad[\mathrm{USD}]
$$

gdzie:

$K_{11}$ - koszt gazowca LNG,

$K_{12}$ - koszty związane ze stratą załogi,

$K_{13}$ - koszty utraty ładunku,

$K_{14}$ - koszty akcji ratowniczej.

Przyjęto:

- koszt gazowca LNG o pojemności ładunkowej $145.000 \mathrm{~m}^{3}$ wynosi około $80 \mathrm{mln}$. USD,

- koszt związany z utratą 30-osobowej załogi wynosi około $30 \mathrm{mln}$. USD,

- koszt ładunku przy statku załadowanym wynosi około $30 \mathrm{mln}$. USD,

- koszty dwudniowej akcji ratunkowej na Bałtyku wynoszą około 500 tys. USD. 
Po obliczeniu określono koszty skutków kolizji na odcinku 1 jako równe:

$$
\begin{array}{ll}
S_{e 1}=140,5 \mathrm{mln} . \mathrm{USD} & \text { (statek załadowany), } \\
S_{e 1}=110,5 \mathrm{mln} . \mathrm{USD} & \text { (statek pod balastem). }
\end{array}
$$

Na odcinku 2 dominującym zagrożeniem jest wejście gazowca LNG na skarpe pogłębionego toru wodnego, a średnie skutki takiego wypadku wynoszą $S=5,4$. Przewiduje się, że tego typu wypadek $(S \leq 10)$ nie spowoduje rozszczelnienia zbiorników, może spowodować lokalne uszkodzenie kadłuba $[1,2]$. Wymaga on zorganizowania akcji ratunkowej (ściagnięcie gazowca $\mathrm{z}$ mielizny) i przeglądu oraz ewentualnego remontu uszkodzonego kadłuba.

Koszty oceny skutków tego typu wypadku można określić następująco:

$$
\left.S_{e 2}=\sum_{j=1}^{2} K_{2 j} \quad \text { [USD }\right]
$$

gdzie:

$K_{21}$ - koszt usunięcia skutków wypadku statku,

$K_{22}$ - koszty wynikające ze strat spowodowanych zablokowaniem drogi wodnej.

Usunięcie skutków wejścia na mieliznę gazowca generuje koszty związane z następującymi przyczynami:

- akcja ratownicza,

- remont statku,

- wyłączenie z eksploatacji statku w czasie trwania akcji ratowniczej i jego remontu.

Koszt usunięcia skutków wypadku statku określono wykorzystując metodykę opracowaną w „Inżynierii ruchu morskiego" [1], w której sumaryczną moc holowniczą niezbędną do ściągnięcia statku z mielizny, czas postoju na doku i zakres remontu określane są w funkcji skutków wypadku $(S=5,4)$. Wykorzystując te wielkości określono:

- niezbędną dodatkową moc holowniczą niezbędną do zejścia z mielizny jako równą $12.000 \mathrm{KM}$,

- czas akcji ratowniczej: 1 doba.

Koszty wynikające ze strat spowodowanych zablokowaniem portów w jednym przypadku Szczecina i Świnoujścia w drugim Portu Północnego w Gdańsku ograniczono do kosztów przestoju statków na redzie i w porcie, które określono w oparciu o intensywność ruchu i średnią wielkość statku zawijającego do tych portów. 
Intensywność ruchu w tych portach prognozowaną na 2015 rok można przyjąć następująco [2]:

- Port Świnoujście-Szczecin - 12.000 [liczba statków w roku]

$$
\text { (średni statek - } 5.000 \text { DWT), }
$$

- Gdańsk - Port Północny - 1.000 [liczba statków w roku] (średni statek $-\sim 20.000$ DWT).

W oparciu o powyższe założenia określono przybliżone koszty akcji ratowniczej, koszt remontu i wyłączenia gazowca LNG z eksploatacji oraz koszty przestojów statków na redzie i w porcie związane z zablokowaniem drogi wodnej przedstawiono w tabeli 1.

Tabela 1. Koszty akcji ratowniczej, remontów oraz przestoju statku przeliczone na 1 wypadek o średnich skutkach

\begin{tabular}{|c|c|c|c|c|}
\hline Port & $\begin{array}{c}\text { Koszty } \\
\text { akcji } \\
\text { ratowniczej }\end{array}$ & $\begin{array}{c}\text { Koszty } \\
\text { remontu } \\
\text { i wyłączenia } \\
\text { statku } \\
\text { z eksploatacji }\end{array}$ & $\begin{array}{c}\text { Koszty } \\
\text { przestoju } \\
\text { statków } \\
\text { na redzie } \\
\text { i w porcie }\end{array}$ & $\begin{array}{c}\text { Koszty } \\
\text { oceny } \\
\text { skutków } \\
\text { wypadku na } \\
\text { odcinku } 2 \\
S_{e 2}\end{array}$ \\
\hline Port Świnoujście & $\begin{array}{c}200.000 \\
\text { USD }\end{array}$ & 700.000 USD & 300.000 USD & 1,2 mln USD \\
\hline $\begin{array}{c}\text { Gdańsk- Port } \\
\text { Północny }\end{array}$ & $\begin{array}{c}200.000 \\
\text { USD }\end{array}$ & 700.000 USD & 100.000 USD & 1 mln USD \\
\hline
\end{tabular}

$\mathrm{Na}$ odcinku 3 dominującym zagrożeniem jest zderzenie gazowca LNG $\mathrm{z}$ konstrukcjami hydrotechnicznymi lub cumującymi $\mathrm{w}$ porcie innymi statkami, a średnie skutki takiego wypadku wynoszą $S=1$. Przewiduje się, że tego typu wypadek nie spowoduje rozszczelnienia zbiorników może jedynie spowodować wgniecenie lub przebicie kadłuba. Nie wymaga organizacji akcji ratunkowej ani nie spowoduje zblokowania drogi wodnej. Koszty oceny skutków tego typu wypadków można określić następująco:

$$
S_{e 3}=\sum_{j=1}^{2} K_{3 j} \quad[\mathrm{USD}]
$$

gdzie:

$K_{31}$ - koszt usunięcia skutków wypadku statku,

$K_{32}$ - koszty usunięcia skutków wypadku budowli hydrotechnicznych lub cumujących w porcie innych statków. 
Koszty usuwania skutków wypadku gazowca LNG sprowadzają się jedynie do kosztów jego remontu i wyłączenia statku na ten czas z eksploatacji. Uwzględniając małe skutki wypadku $(S=1)$ przyjęto z pewnym przybliżeniem, że $K_{31} \approx K_{32} \approx 100.000$ USD, czyli:

$$
S_{e 3}=0,2 \mathrm{mln} \text {. USD. }
$$

Ryzyko ekonomiczne poszczególnych wariantów lokalizacji terminalu LNG przedstawiono w tabeli 2 .

Tabela 2. Ryzyko ekonomiczne badanych wariantów lokalizacji Terminalu LNG

\begin{tabular}{|c|c|}
\hline Wariant lokalizacji & $\begin{array}{c}\text { Ryzyko ekonomiczne } R_{e} \\
\text { [USD/rok] }\end{array}$ \\
\hline $\begin{array}{c}\text { Port Świnoujście } \\
\text { wariant 1 } \\
\text { wariant 2 }\end{array}$ & $0,815 \mathrm{mln}$ \\
\hline Gdańsk - Port Północny & $0,815 \mathrm{mln}$ \\
wariant 1 & \\
wariant 2 & $1,63 \mathrm{mln}$ \\
wariant 3 & $1,77 \mathrm{mln}$ \\
\end{tabular}

Analiza ryzyka ekonomicznego poszczególnych wariantów lokalizacji terminalu LNG (Tabela 2) pozwala na jednoznaczne stwierdzenie, że ryzyko ekonomiczne jest dwukrotnie mniejsza dla lokalizacji świnoujskiej $\left(R_{e} \approx 0,8\right.$ $\mathrm{mln}$. USD/rok) W porównaniu $\mathrm{z}$ lokalizacją gdańską $\left(R_{e} \approx 1,6 \mathrm{mln}\right.$. USD/rok).

\section{Wnioski}

W artykule zaprezentowano porównawczą metodę określenia ryzyka nawigacyjnego i ekonomicznego na trasie żeglugowej składającej się z odcinków, na których występują różne zagrożenia, i na których statki poruszają się różnymi prędkościami. Opracowaną metodę zastosowano do wyboru najbezpieczniejszej lokalizacji terminali LNG na wybrzeżu polskim. Przeanalizowano 2 szczegółowe warianty lokalizacji terminalu LNG w Porcie Świnoujście (rys. 1, 2) i 3 szczegółowe warianty w Porcie Północnym w Gdańsku (rys. 3). 
Stwierdzono, że bezpiecznymi wariantami lokalizacji terminalu są:

- Port Świnoujście: 1 i 2 wariant lokalizacji - ryzyko nawigacyjne $\mathrm{R}=$ $1,186 \cdot 10^{-2}$,

- Port Północny w Gdańsku: wariant 1 - ryzyko nawigacyjne $\mathrm{R}=1,348$ $\cdot 10^{-2}$.

Najbezpieczniejszymi, $\mathrm{z}$ punktu widzenia przejścia gazowca LNG o pojemności ładunkowej $145.000 \mathrm{~m}^{3} \div 200.000 \mathrm{~m}^{3}$ od cieśnin duńskich do terminalu LNG, są oba warianty lokalizacji terminalu w Porcie Świnoujście. Badania dotyczace wyboru optymalnej lokalizacji terminalu LNG przeprowadzono również $\mathrm{w}$ oparciu o kryterium minimalizacji ryzyka ekonomicznego, gdzie także wykorzystano wyniki badań symulacyjnych.

Stwierdzono, że ryzyko ekonomiczne jest dwukrotnie mniejsze dla lokalizacji świnoujskiej:

- Port Świnoujście: 1 i 2 wariant lokalizacji - ryzyko ekonomiczne $\left(R_{e} \approx 0,8 \mathrm{mln}\right.$. USD/rok),

- Port Północny w Gdańsku: wariant 1 - ryzyko ekonomiczne $\left(R_{e} \approx 1,6\right.$ $\mathrm{mln}$. USD/rok).

Porównując realne warianty lokalizacji terminalu LNG na wybrzeżu polskim przy wykorzystaniu metod ryzyka nawigacyjnego i ekonomicznego określono, że najbezpieczniejszym miejscem jego lokalizacji jest port zewnętrzny w Świnoujściu.

Założenia i przybliżenia przyjęte przy szacowaniu ryzyka ekonomicznego są dopuszczalne ze względu na porównawczy charakter zastosowanej metody gdyż podobne błędy są popełniane przy szacowaniu ryzyka ekonomicznego dla każdego z porównywanych wariantów.

Artykut powstat $w$ ramach projektu rozwojowego: Opracowanie najbardziej efektywnego rozwiqzania budowy morskiego terminalu rozładunkowego gazu plynnego LNG w Polsce. Określenie optymalnych parametrów terminalu dróg wodnych prowadzacych do niego oraz warunków jego bezpiecznej eksploatacji o numerze R10 00501 finansowanego przez Ministerstwo Nauki $i$ Szkolnictwa Wyższego.

Professor STANISLAW GUCMA, Ph.D., D.Sc., captain, full professor at the Maritime University of Szczecin. Specialisation: inżynieria ruchu morskiego. 
